\author{
BÖRÖNDI-FÜLÖP Nikoletta, \\ AMBRUZS Márta Anett \\ Kaposvári Egyetem \\ Gazdaságtudományi Kar, \\ Marketing és Kereskedelem Tanszék \\ (University of Kaposvár, \\ Faculty of Economic Science, \\ Department of Marketing and Trade) \\ H-7400 Kaposvár, Guba S. u. 40 \\ e-mail cím: a.anettambruzs8@gmail.com
}

\section{AZ ÉRZÉKSZERVEK HATÁSA A BORVÁSÁRLÁSRA ÉS -FOGYASZTÁSRA}

\author{
THE EFFECTS OF SENSORY ORGANS \\ ON WINE PURCHASE AND CONSUMPTION
}

\begin{abstract}
Interest in wine has grown in the recent decades. The examination of consumer behavior has become more and more important in countries with highly-developed wine cultures, which is a result of the developing market, the expending supply, the strengthening competition as well as the diverse demands (Hofmeister $\mathcal{E}$ Totth, 2004). Similarly to food consumption, wine consumption is also influenced by several factors. The purchasing decision is influenced by biological, economic, demographic, psychological, social and cultural factors. Sensory marketing is related to the biological factors from the factors in the above because it focuses on sensation and sensory perception (Lebota, 200I). Seeing is the most intensive among our sensory organs, as we perceive $80 \%$ of the information from the world with our eyes. With the help of this we can recognize possible changes in the appearance of a product; we perceive the different design, colors, packaging, forms and materials. Thus, appearance is the most significant element of sensory marketing. When the appearance of a product is appealing, it will be able to satisfy functional as well as emotional needs (Tóbiás, 20Io). The complex experience provided by wine consumption is triggered by the simultaneous interaction of several sensory organs $(B e c k e r \mathcal{E}$ Izsó, 201 I). In our primary research we examined the role of the elements of sensory marketing in wine purchasing and consumption habits. In our focus group interviews we discussed participants' wine purchasing and consumption habits and the factors influencing purchase. Finally, we examined the effects triggered by sensory organs with the help of wine tastings.
\end{abstract}

Keywords: wine, sensory, consumption, purchase, vision

JEL code: M3 Io

\section{BEVEZETÉS}

Az utóbbi években, évtizedekben a bor iránti érdeklődés megnövekedett. A fejlett borfogyasztási kultúrával rendelkező országokban egyre nagyobb jelentőséggel bír a fogyasztók magatartási szokásainak vizsgálata. Mindezt a piac fejlődése, a kínálat bővülése, az erősödő verseny, illetve a szerteágazó kereslet teszi szükségessé (Hofmeister-Tóth E Totth, 2006).

Ahogy az élelmiszer-fogyasztást, úgy a borfogyasztást is számos tényező befolyásolja. A vásárlási döntésre hatással vannak a biológiai, közgazdasági és demográfiai, pszichológiai, társadalmi és kulturális tényezők. Az érzékszervi marketing ezen tényezők közül a biológiai tényezőkhöz kapcsolódik, hiszen ez az érzékszervi érzékeléssel és észleléssel foglalkozik. A fogyasztók az élelmiszerek tulajdonságait érzékszervek segítségével érzékelik (Lehota, 200I).

Az érzékszervi marketing gyakran csupán a termékek természetes tulajdonságára hívja fel a figyelmet, ezáltal elősegíti az érzékelést. Ez a marketingmódszer azért alkalmas a fogyasztók meg- győzésére, mert nem tủnik reklámnak, ezáltal a vásárlók az ösztöneikre, érzékeikre hagyatkozva döntenek az adott termék mellett (Mannhardt, 2016). Élelmiszer-fogyasztás során a fogyasztókat többféle inger éri, különböző forrásokból. Legjelentősebb tényező az ízlelés, négy alapízt különböztetünk megः édes, savanyú, sós, keserü. Minden fogyasztó eltérő ízpreferenciával rendelkezik (Horváth E Fürediné Kovács, 2010). Az ízérzékelésre hatással van a látás, tapintás, szaglás és a hallás is. A vizuális élmények megalapozzák az ízélményt, hiszen létrehoznak egy előzetes várakozást. A tapintásnak is fontos szerepe van az íz érzékelésénél, mivel nem mindegy, milyen anyagból készült az evőeszköz, a tányér vagy a pohár, amiből elfogyasztjuk az ételt vagy italt. Emellett a pohár hőmérséklete is meghatározó lehet. Ezekből következik, hogy az ízlelés egy komplex folyamat, amelyben az összes érzékszerv szerepel (Marketinginfo.bu, 20I6). A szaglás nemcsak az ételek illatának érzékelése miatt lényeges, hanem az ízek érzékelésében is szerepet játszik. Az ízeket kizárólag aromaként érzékeljük, mivel az ízre érzékeny idegsejtek a szaglóközpontban helyezkednek el, 
ami az orr csúcsán található. Érdekesség, hogy a szaglóidegsejtek több ezer ízt tudnak megkülönböztetni, míg az ízlelőbimbók csak az alapízeket érzékelik. Az agyhoz akkor tudnak eljutni a molekulák, ha páraként kiválnak a folyadékból. Borfogyasztásnál emiatt van nagy jelentősége, hogy kóstolás előtt a bort körbeforgassuk a pohárban (N. n., é.n.). Látásunk segítségével az ételek szín és formavilágát tudjuk értékelni, továbbá a bőr és a fül az élelmiszerek szerkezetének észlelését biztosítják. Azonban az érzékelés fiziológiai, társadalmi és pszichológiai hatásai miatt a fogyasztók a valóságtól eltérően érzékelhetnek (Horváth E Fürediné Kovács, 2010).

A borfogyasztás által nyújtott komplex élményt egyszerre váltja ki több érzékszerv interakciója. A bor íze mellett kiemelkedően fontos annak látványa és illata is (Becker E Izsó, 20II). Érzékszerveink közül a látás a legintenzívebb, hiszen szemünkkel fogjuk fel a külvilágból érkező információ 80\%-át. Látásunk segítségével fel tudjuk ismerni, ha valami változás következik be egy termék megjelenésében, érzékeljük az eltérő designt, színeket, csomagolást, formákat vagy anyagokat. Emiatt a megjelenés az érzékszervi marketing legfontosabb eleme. Ha egy termék esztétikus megjelenésű, akkor a funkcionális szükségletek mellett érzelmi szükségleteket is ki tud elégíteni (Tóbiás, 2010).

Napjainkban egy ingerekkel túltelített és gépesített világban élünk. A csomagolás hatásos eszköz a fogyasztók érdeklődésének felkeltésére, hiszen képes érdeklődést és érzelmeket kiváltani. Amikor a fogyasztó a boltokban áll a polcok elött, számos hasonló termékkel találja magát szembe. Gyakran néhány másodperc alatt kell döntenünk, hogy melyik terméket vásároljuk meg, ilyenkor a csomagolás által közvetített emocionális többlet nagyban hozzájárul a döntéshez. Fontos, hogy a csomagolás minél intenzívebb élményt váltson ki a fogyasztóban, így a megvilágításnak, színeknek, formának és a használt anyagoknak is jelentős szerepe van. Ezáltal a látás mellett az érzés, szaglás és a tapintás is szerepet kap (Jurasits, 2003).

\section{ANYAG ÉS MÓDSZER}

A borfogyasztás, illetve -vásárlás témájában rengeteg szakirodalmi anyag áll rendelkezésre, azonban az érzékszervek és a borvásárlás, illetve borfogyasztás kapcsolatát vizsgáló irodalmak között csak néhány releváns kutatási anyag található, ezért is volt nagyon fontos, hogy primer kutatást készítsünk.

A primer adatgyüjtés során kvalitatív kutatásokat végeztünk, összesen I 6 emberrel, 20I7 szeptemberében. Két alkalommal tartottunk fókuszcsoportos interjút, két egymást követő napon. Egy fókuszcsoportos interjú alkalmával 8 ember vett részt a beszélgetésben, mindkét esetben vegyes csoport-összetételűek voltak az interjúk. Az interjún résztvevő személyek I8 és 30 év közöttiek voltak. Az első csoport résztvevői munkahellyel rendelkeztek, míg a második csoport résztvevői kizárólag egyetemi hallgatók voltak. A célcsoportok szétválasztását indokolja, hogy eltérő szempontok játszhatnak szerepet egy keresettel rendelkező személy, illetve egy egyetemista vásárlási döntésében. Az interjú során elöször beszélgettünk a résztvevőkkel a borvásárlási, illetve -fogyasztási szokásaikról. Az ezt követő feladatban nyolc vörösborról mutattunk képet a résztvevőknek, és arra kértük őket, hogy a borok vizuális megjelenése alapján állítsanak fel egy sorrendet, hogy melyiket vásárolnák meg legszívesebben. A harmadik feladatban boroscímkéket mutattunk nekik, ennél a feladatnál átbeszéltük, hogy mit kedvelnek a címkékkel kapcsolatban, illetve milyen információkra figyelnek.
Az interjú zárásaként egy borkóstolót tartottunk két borral, amelyet kóstolás előtt szóban, illetve kóstolás után egy értékelőlapon kellett értékelniük a résztvevőknek I-től 5 -ig pontozva. Az interjút követően az értékelőlapokat Excel program segítségével értékeltük ki.

\section{EREDMÉNYEK ÉS ÉRTÉKELÉSÜK}

\section{3+I+Borvásárlási szokások}

A borvásárlás gyakoriságát tekintve nagyon széles skálán mozogtak a válaszok. A résztvevők fele havonta, többen hetente, illetve 2-3 hetente vásárolnak bort. Azonban néhány résztvevő csak évente 2-3 alkalommal vásárol bort.

A vásárlás helyei elsősorban a nagyobb szuper-és hipermarketek, de termelőtől és háztól szintén szoktak vásárolni a résztvevők. A borszaküzleteket egyik csoportban sem említették meg, emiatt erre külön rákérdeztünk. A borszaküzleteket egyöntetűen nem részesítik előnyben annak magas ára miatt.

A válaszadók többsége saját fogyasztás mellett ajándékba, különböző alkalmakra, baráti összejövetelekre is szokott vásárolni bort.

A vásárlást befolyásoló tényezők közül a legfontosabb a márka és az ár. Ez mindkét csoport esetében az első két helyen állt, annyi különbéggel, hogy az egyetemista csoport az árat veszi figyelembe elsődlegesen, míg a keresettel rendelkezők számára fontosabb, hogy márkás bort vásároljanak. Ezek után következik a csomagolás, amelynek szerepe főleg ajándékvásárlás esetén hangsúlyos. Mindezek mellet a résztvevők nagy figyelmet fordítanak az édességi kategóriára és a borfajtára. A pincészetet, borvidéket és az évjáratot csak néhányan említették meg. Borvidékek tekintetében kiemelendő a villányi, ehhez a borvidékhez a megkérdezettek egyöntetüen a minőséget kötik.

Mivel a fókuszcsoportos interjúink résztvevői nem borszakértők voltak, ezért kíváncsiak voltunk arra, hogy az előbb említett tényezők közül mit vesznek figyelembe a vásárlásnál, ha minőségi terméket akarnak vásárolni. Ebben az esetben teljes mértékben egyetértettek a válaszadók abban, hogy a külsőségek, illetve a címkén lévő információk alapján tudnak dönteni egy adott termék mellett. Ilyen esetben megnéznék a címke formáját, grafikai elemeit, a palack formáját. Ezt követi a márkanév és az ár. Hiszen, aminek ismert neve van és magas ára, az valószínűleg jó minőségű lehet véleményük szerint.

\section{3+2* Borfogyasztási szokások}

Minden megkérdezett fogyaszt bort, azonban jelentősen eltérő mennyiségben és gyakorisággal. A válaszadók között akadtak olyanok, akik hetente elfogyasztanak akár egy üveg bort, illetve vannak olyanok is, akik éves szinten I-2 alkalommal, kizárólag 2-3 dl bort fogyasztanak. A megkérdezettek fele havonta, illetve néhány havonta, egy kicsivel kevesebben hetente, kéthetente fogyasztanak bort. Ök általában baráti társaságban, hétvégenként, bulik alkalmával vagy vacsora után fogyasztanak bort. A válaszadók között többen I-2 üveg bort is elfogyasztanak egy baráti társaságban, azonban vannak, akik néhány decinél nem fogyasztanak többet. Néhány résztvevő csupán évente I-2 alkalommal fogyaszt bort, családi események, névnapok, születésnapok alkalmából.

A válaszadók több mint fele vörösbort fogyaszt legszívesebben, ettől nem sokkal marad el a fehérborok kedveltsége. A rozék ked- 
veltsége jelentősen elmarad az előbb említett két borfajtától, csupán néhány megkérdezett fogyaszt legszívesebben rozét. A vörös- és fehérborokat tisztán, míg a rozékat könnyű fröccsként fogyasztják el leggyakrabban. A résztvevők fele az édes borokat kedveli, majd ezután a száraz borok kedveltsége következik. A félédes és félszáraz borokat egyaránt 2-2 személy említette meg. Ez az eredmény meglepetést okozott, mivel a vörösborok kedveltsége áll első helyen, emiatt azt feltételeztük, hogy a száraz borokat fogják említeni többen, azonban a megkérdezettek többsége vörös- és fehérborokban is az édes változatot kedveli jobban. A keresettel rendelkező csoporttagok egyértelműen az édes borokat kedvelik, míg az egyetemisták között voltak olyanok, akik kizárólag száraz vörösborokat fogyasztanak.

\section{3+3. Borvásárlási szituáció}

Ehhez a feladathoz előzetesen nyolc borról kerestünk képet, amelyből elkészítettünk egy összeállítást. A feladat az volt, hogy állítsák sorba a nyolc bort, első helyre kerüljön az a bor, amelyet legszívesebben megvásárolnának és utolsó helyre pedig az, amelyet semmiképp nem emelnének le egy bolt polcáról. Vörösborokat választottunk, annak érdekében, hogy ne a kedvelt borszín alapján állítsanak fel egy rangsort, hanem kizárólag a csomagolás megjelenése és a címkén lévő információk alapján döntsenek. A borok között megjelent márkás villányi, illetve francia bor, bohókás címkéjü bor, sőt még PET-palackos és ötliteres kiszerelésű bor is.

A résztvevők a borok többségét nem ismerték, emiatt az első szempont, amit figyelembe vettek, hogy igényes, egyszerü, meggyőző címkéje legyen, illetve ehhez egy szép üvegforma kapcsolódjon. A címkéknél kiemelték, hogy ne legyen túldíszített, túl színes a minta, és harmonizáljanak a színek. A bor eredetét is sokan figyelembe vették, a villányi borvidék borait egyértelműen minőséginek gondolták, valamint a francia borról is hasonlóan vélekedtek. Egyik résztvevő sem részesítette előnyben a nagy kiszerelésű bort és a PET-palackos terméket. PET-palackos bort mindenki csak akkor vásárol, ha abban házi bor van vagy termelőtől vásárolt folyóbor.

A következő feladat során a résztvevők számos különböző formájú és megjelenésű palackot láttak. Az üvegforma tekintetében a bordói palackformát kedvelik legtöbben, mivel ez az, amivel leggyakrabban találkoznak a boltokban. Üvegszín tekintetében az átlátszó palackot kedvelik fehérborok és rozék esetében is. Vörösboroknál egyértelműen a sötétebb barna és zöld árnyalatot részesítik elönyben. A fehérborokat zöld, illetve barna palackokban is árulják, azonban ezeket a megoldásokat egyik résztvevő sem említette meg.

Manapság egyre több borászat alkalmazza a csavarzáras kupakot, emiatt kíváncsiak voltunk hogyan vélekednek erről a kérdésről a résztvevők. A válaszadók a parafa dugós lezáráshoz egyöntetűen a minőséget kötik. A parafa dugó alkalmazása egy régi, hagyományos dolog, amely egy megszokott hangulatot ad a borozásnak. Igaz, hogy a csavarzár praktikusabb, de egy karakteres vörösborhoz egyáltalán nem tudnák elképzelni a válaszadók.

\section{3+4. Címkevizsgálat}

A legtöbb információt a címke szolgáltatja az adott borról. A hátcímkének kötelezően előírt információkat kell tartalmaznia a fogyasztók tájékoztatása érdekében.
A résztvevők az összes információt felsorolták, ami szerepelhet egy címke hátoldalán. Legfontosabbnak azt tartották, hogy milyen fajtájú a bor, illetve milyen a cukortartalma. A többség rendelkezik egy kedvelt fajtával, és elsősorban azt keresi az üzletekben. Fontosnak tartják a bor származási helyét és a borvidéket. A hazai termékeket keresik leggyakrabban, csak kíváncsiságból, különlegességként próbálnak ki külföldi borokat. Borvidék tekintetében a villányi és szekszárdi borvidék borait kedvelik leginkább. A márka is említésre került, főleg ha egy ismert márkáról van szó, akkor könnyen be tudják azonosítani, hogy milyen kategóriájú, minőségủ lehet a bor. A borvásárlásnál jelentősége van, hogy milyen alkalomra vásárolják a terméket, emiatt kedveltek a címkén szereplő ajánlások. Az ajánlásokban általában leírják, hogy milyen ételekhez, illetve alkalmakhoz illik a termék. A bor minőségét jelölő feliratokat is többen meg szokták nézni, hiszen minőségi termékeket szeretnének vásárolni. Valamint, ha az adott bor kapott díjat vagy jó minősítése van, akkor szívesebben megvásárolják. Ezek az elemek, illetve az aranyozott motívumok figyelemfelkeltőek. Néhány résztvevő bevallotta, hogy egyáltalán nem ért a borokhoz, ezért csak arra hagyatkozik, amit a fócímkén lát, ha megtetszik neki a logó, illetve a grafikai elemek, akkor megvásárolja a bort. Egy-két ember említette meg a termelőt, évjáratot, pincészetet és az alkoholfokot. De ezek a jellemzők nem tartoznak a fó befolyásoló tényezők közé.

Külön kitérve a föcímke grafikai elemeire, a megkérdezettek előnyben részesítik az egyszerü, régiesebb stílusú, klasszikusabb címkéket. Ajándék esetében fontos, hogy a címke legyen kreatív, harmonizáljanak a színek, azonban ne legyen túldíszített. A címke megjelenésének összhangban kell lennie a palackformával, ami egy olyan összhatást eredményez, hogy szívesen megvásárolják a fogyasztók a terméket.

\section{3+5. Borkóstoló}

A fókuszcsoportos felmérés utolsó szakaszában azt vizsgáltuk, hogy az érzékszervek, az előzetes benyomások hogyan befolyásolják az ízérzékelést. Kísérleti jelleggel azonos bort töltöttünk két különböző palackba. A két üveg erős eltérést mutatott. Az első üveg bor egy Dél-Afrikából származó merlot bor palackjában volt. Mint ahogy az 1. ábra is mutatja, a címkén egy szőlészet képe látható, szőlőlugasokkal. Egy aranyozott matricát is elhelyeztek a címke felett, amin egy szőlöfürt van, a kupak és a kapszula is díszített. A második alkalommal egy Magyarországról származó kékfrankos merlot üvegébe töltöttülk a kóstolásra kerülő bort. A 2. ábrán látható a bor fehér alapú címkéje, amin egy, az ismert Magyar népmesékrajzfilmsorozatot idéző egyszerű madárfigura látható.

A kóstolási kísérletnél abból a feltételezésből indultunk ki, hogy a résztvevők azt a bort fogják finomabbnak tartani, amelynek a csomagolása is jobban tetszik nekik. Hiszen, ha egy vizuális elem, szín vagy akár egy hangulat felkelti a fogyasztók figyelmét, akkor tudnak kötődni az adott termékhez, ezáltal pozitívan ítélik meg azt.

A felmérés során első lépésként arra kértük a résztvevőket, hogy jól nézzék meg a két palackot, és mondják el, melyik tetszik jobban. Ezt követően egy értékelőlapon néhány megadott tényező alapján osztályozniuk is kellett egytől ötig, az iskolai osztályzatoknak megfelelően a két üveget. A vizsgált szempontok a palackforma, palackszín, címke formai megjelenése, annak információtartalma és a csomagolás összhatása voltak. A külső tényezők 
I+ ábra: Az afrikai bor címkéje

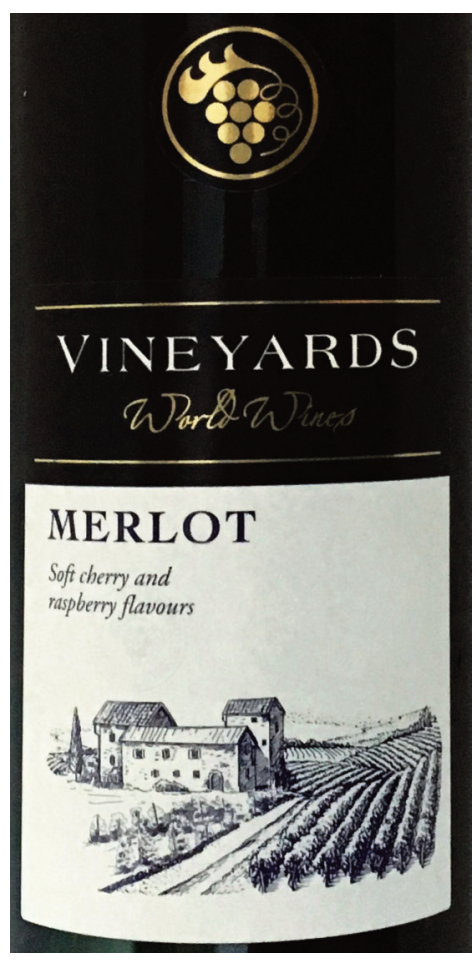

Fotó: Szerzők

értékelését összefoglalva elmondható, hogy jelentős eltérések találhatók a két termék csomagolásának vizuális megítélése között. Mivel a választott palackok formája megegyezett, így nem meglepő, hogy ezt a tényezőt egyformán jónak ítélték a jelenlévők. Ezt leszámítva azonban minden vizsgált elem és az összbenyomás tekintetében is az első, dél-afrikai bor csomagolása bizonyult jobbnak. A legjelentősebb eltérés a címke formai megjelenése esetén volt tapasztalható. A megkérdezettek több mint háromnegyede az első bor címkéjét értékelte jobbnak. Az összbenyomás alapján a résztvevők jelentős része az első palackot részesítette előnyben, míg a másodikat összesen egy ember értékelte jobbnak.

A csomagolás szóbeli értékelése alapján elmondható, hogy a többségnek az afrikainak hitt bor tetszett jobban, ők ezt kóstolnák meg szívesebben. A címkét nagyon szépnek, kidolgozottnak találták. Tetszett nekik, hogy látható a címkén szőlő, borászat képe, ebből mindannyian azt feltételezték, hogy az adott bor tényleg szőlőből készült. Különösen felkeltette a figyelmüket az aranyozott, szőlőt ábrázoló matrica, illetve a kupak díszítése is. Néhányan a címkén található információk tekintetében marasztalták el ezt a címkét a magyar címkéhez képest. Hiányolták a részletes leírást az elsőként mutatott borról, a hátcímkéről csak a borfajtát, alkoholfokot és a származási országot tudták leolvasni. Akiknek az első bor tetszett jobban, egyaránt úgy gondolták, hogy a második, madarat ábrázoló címke nagyon elnagyolt, feltehetően egy olcsó borhoz készíthették, nem sugall minőséget.

Három ember volt a csoportban, aki úgy gondolta, hogy a „kevesebb néha több", ezért megelégednek az egyszerű grafikával is. Hiszen sokkal részletesebb leírást olvastak a második borról, és mégiscsak egy magyar termékről van szó. Ugyan ők is elismerték, hogy sokkal szebb az afrikainak gondolt bor csomagolása, de ennek ellenére a magyarnak vélt bort vásárolnák meg szívesebben.

A borok csomagolásának értékelését a kóstolás követte. Az értékelés a csomagoláshoz hasonlóan egy egytől ötig terjedő skálán
2. ábra: A magyar bor címkéje

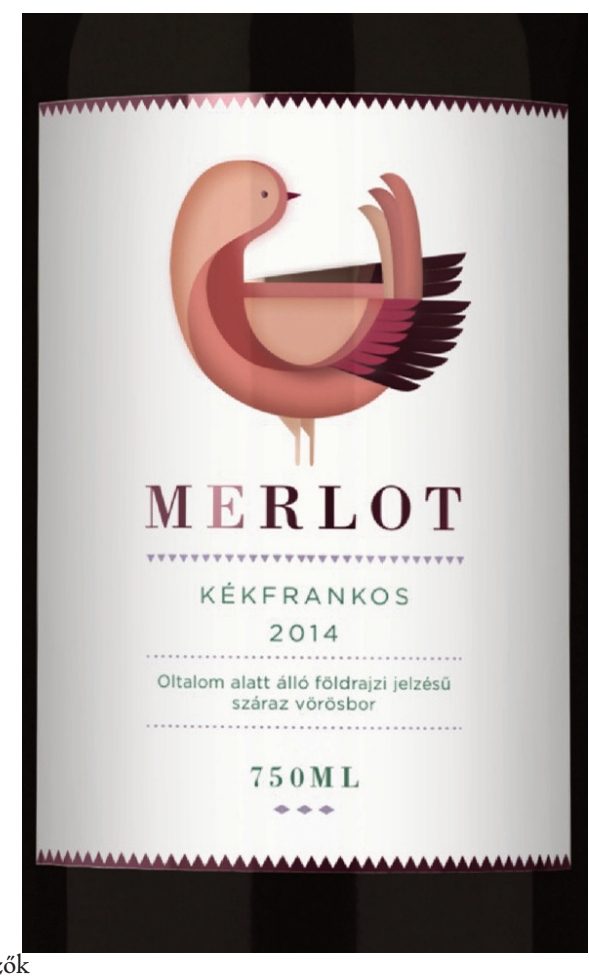

Fotó: Szerzők

történt az iskolai osztályzatoknak megfelelően. A vizsgált szempontok az alábbiak voltak:

+ tisztaság,

+ szín,

+ illat,

$+1 z$,

+ utóíz,

+ teltség/testesség,

+ összbenyomás.

A kóstolás körülményei teljesen megegyeztek mindkét minta esetén, tehát ugyanolyan pohárból, egyforma hőmérsékleten és mennyiségben kínáltuk először az afrikainak vélt, minőségi, majd a magyarnak hitt, olcsó bort. A feltételezésekkel ellentétben azonban mindkét esetben ugyanaz az ital került kitöltésre, csak a két, különböző minőséget és származást sugalló palackból.

Az első és legszembetűnőbb eredmény, hogy egyik résztvevőben sem merült fel a gondolat, hogy ugyanazt a bort issza, sőt jelentős különbségeket éreztek a két minta között.

A kóstolás során minden vizsgált tényező esetén különbségek érzékelhetők a megítélésben. A borok tisztaságát vizsgálva elég egységes volt a megítélés, azonban a szín tekintetében már nagyobb különbségek mutatkoztak. Ez a szempont osztotta meg leginkább az alanyokat, a többség ebben az esetben a magyarnak vélt bor színét ítélte jobbnak. Az összes többi szempont esetén összefoglalva elmondható, hogy a drágább, minőségibbnek vélt bort ugyanúgy vagy jobbnak értékelték, mint az olcsóbb kategóriájúnak véltet. Egyéni szinten vizsgálva azonban jól látszódott, hogy amelyik bor palackját jobbnak ítélték, és azt nyilatkozták róla, hogy szívesebben megkóstolnák, azt többnyire az ízteszt alapján is jobbnak ítélték. Ez alól csak néhány jelenlévő volt kivétel, ők mindannyian az afrikai bor csomagolását vélték tetszetősebbnek, de íz alapján a magyar bort tartották jobbnak. A beszélgetés során mindannyiuk esetében erős magyarságtudat volt érzékelhető, és büszkeséggel 
töltötte el őket, hogy a magyarok nagyon jó, nemzetközi szinten is versenyképes borokat tudnak gyártani. Egy véleményt szeretnénk idézni a magyarnak hitt bor mellett szólóktól:

„Sokkal szebb a színe, igazi vörösborhoz illik. Az íze karakteres, nagyon kellemes illata van. Nincs olyan savanykás íze, mint az első bornak. Egy jó borozás alkalmával szívesen elfogyasztanám vagy akár egy pörköltbe is beleraknám."

Ez alapján megfontolandónak véljük, hogy a vizsgálatot a nemzetiségi tudatra irányítottan is érdemes lenne elvégezni.

\section{KÖVETKEZTETÉSEK ÉS JAVASLATOK}

Kutatási eredményeink alapján is elmondható, hogy Magyarországon jelentősnek mondható a borfogyasztás. Magyarország déli borvidékein elsősorban a vörösborok kiválóak, az eredmények is azt mutatják, hogy a szakirodalommal összhangban ezeket a borokat kedvelik leginkább. Az interjúalanyaink a villányi és a szekszárdi borvidékeket említették meg, főleg ezekről a vidékekről származó borokat vásárolják.

A borvásárlás és a borfogyasztás gyakorisága összhangban van egymással, mivel mindkét esetben a válaszadók több mint fele havonta vásárol, illetve fogyaszt bort. Nemek szerinti eloszlás tekintetében megállapítható, hogy a férfiakra ez némiképp jellemzőbb, mint a nőkre.

A borvásárlást befolyásoló tényezők vizsgálata során arra a megállapításra jutottunk, hogy a magyar fogyasztók árérzékenyek, mivel vásárlásnál az ár az elsődleges, amit figyelembe vesznek. Nagy jelentősége van vásárlásnál a márkáknak, ezért azok a borászatok tudnak sok bort értékesíteni, amelyeknek ismert nevük van a piacon, amihez minőséget tudnak kötni a fogyasztók. Abban az esetben, ha nem ismerik a márkát a fogyasztók, akkor előtérbe kerül a csomagolás jelentősége. Emiatt mindenképpen figyelmet kell fordítani arra, hogy gondos csomagolással kerüljenek piacra a termékek.

A címkék vizsgálata alapján azt a megállapítást tudjuk megfogalmazni, hogy nem feltétlenül elönyös, ha egy címke nagyon modern és színes, mert a fogyasztók jobban kedvelik, ha egy címke klasszikus stílusú, régies megjelenésű, és esetleg plusz grafikai elemekkel van feldobva. Aranyozás, díszítőelemek a kupakon vagy esetleg díjazásra utaló feliratok is fel tudják kelteni az érdeklődést úgy, hogy közben egy minőséget sugallnak. A megjelenés mellett fontos, hogy megfeleló hangsúlyt fektessenek a fogyasztók tájékoztatására is, emiatt előnyös, ha a hátcímke részletes információkat tartalmaz a borról. Itt kifejezetten előnyös lehet, ha ajánlást is feltüntetnek a borhoz kapcsolódóan a kötelező tartalmi elemek mellett.

A borkóstolási kísérlet során bebizonyosodott, hogy az érzékszerveink nagymértékben képesek befolyásolni az érzékelésünket, hatással vannak az ízérzékelésünkre is. A látás kialakíthat egy olyan képzetet, ami alapján jobbnak gondolunk egy terméket egy ugyanolyannal szemben. Ez mutatja, hogy érdemes bevonni az érzékszerveket az értékesítési folyamatba, hiszen egy még nem vagy kevésbé ismert termék esetén az áru sikeressége múlik rajta.

\section{5. ÖSSZEFOGLALÁS}

A kutatásunk elkészítése során felhasznált szakirodalom mennyiségéből és sokrétűségéből is látszik, hogy milyen összetett témáról van szó. Már a szakirodalmi ismeretek alapján látható volt, hogy mit érdemes megvizsgálnunk a primer kutatás során. Az elvégzett fókuszcsoportos interjúk során megismertük a kutatásban résztvevők bor- vásárlási és -fogyasztási szokásai mellett a címkékkel, illetve a teljes csomagolással kapcsolatos preferenciáit, illetve egy saját kísérleti eredménnyel is alá tudjuk támasztani az érzékszervek jelentőségét.

A felmérés során kiderült, hogy a legfontosabb a csomagolás összhatása. A résztvevők kifejezetten fontosnak gondolták, hogy a gondosan elkészített grafika mellett részletes információkat is tartalmazzon a csomagolás. A válaszadók kedvelték a régies stílusú címkéket, megfelelően összeillő színeket és csomagolási elemeket, illetve a hátcímke információi közül az ajánlást is többen kiemelték. A csomagoláson elhelyezett aranyozott részeket, minőségre utaló feliratokat kifejezettek kedvelték. A bor származási helye, a palack formája, színe és a záróelem is jelentősen befolyásolja egy ismeretlen termék esetén a minőség megitélését.

Kutatásunk egyik legérdekesebb része a borkóstoló volt, két alkalommal kóstoltattuk meg a résztvevőkkel ugyanazt a bort, két különböző és eltérő minőséget sugalló palackból. Összefoglalva elmondható, hogy a legtöbb jelenlévő azt a bort ítélte az ízteszt alapján jobbnak, amelyiknek a csomagolását tetszetősebbnek találta, miközben ugyanazt az italt kóstolták, csak két teljesen különböző üvegből. A résztvevők közül senki nem jött rá erre. Az érzékszerveink ilyen nagy hatást tudnak ránk gyakorolni, a gondolataink és érzéseink mellett az ízérzékelésünkre is képesek hatással lenni.

Ezen ismeretek birtokában megfogalmazható, hogy kreatív megoldásokkal, csomagoláson elhelyezett figyelemfelkeltő elemekkel és kiegészítő csomagolási lehetőséggel lehet felkelteni a fogyasztók figyelmét, illetve így az értékesítés is növelhető. Az értékesítés színvonalának fenntartása érdekében a borászatok számára előnyös lenne a piaci igények felmérése, ezáltal olyan címkéket tudnának tervezni, amelyek tényleg megfelelnének a célcsoportjuk igényeinek.

\section{IRODALOM}

(I) Becker, G. \& Izsó, L. (20I I). Termékélmény. Budapest: Akadémiai Kiadó.

(2) Hofmeister-Tóth, Á. \& Totth, G. (2004). Mit kedvel a fogyasztó? - a borvásárlási szokások Magyarországon. Bor és Piac, 3, 26-27.

(3) Hofmeister-Tóth, Á. \& Totth, G. (2006). Fogyasztói szokások alakulása a magyar borfogyasztásban. Az értékek szerepe a borvásárlásban. In: Majoros Pál(szerk): BGF tudományos évkönyv, 2006. (pp. I89-202). Budapest: Budapesti Gazdasági Főiskola.

(4) Horváth, Á. \& Fürediné Kovács, A. (2010). Az élelmiszerfogyasztói magatartás. In Kárpáti, L. \& Lehota J. (szerk.), Agrármarketing. (pp. 34-36). Budapest: Szaktudás Kiadóház Zrt.

(5) Jurasits, J. (2003). A fogyasztóhoz a csomagoláson keresztül vezet az út. Letöltés dátuma: 2017.09. I0, forrás: http://www.omikk.bme.hu/collections/mgi_fulltext/marketing/2 003/08-09/0804.pdf

(6) Lehota, J. (200I). Élelmiszer-gazdasági marketing. Budapest: Müszaki Könyvkiadó.

(7) Mannhardt, A. (20I6). Országos kompetenciamérés 2016. Io. évf. A füzet. Letöltés dátuma: 2017. I0. I5. forrás: https://www.oktatas.hu/pub_bin/dload/kozoktatas/meresek/ors zmer2016/OKM2016_Io_evfolyam_A_fuzet.pdf

(8) Marketinginfo.hu. (20I6). Ízlelési szokásainkat kutatta a CocaCola. Letöltés dátuma: 2017. október 5 , forrás: http://www.marketinginfo.hu/hirek/article.php?id $=42478$

(9) [N. n.]. [é. n.]. Boriskola. Letöltés dátuma: 2017. 09. 22., forrás: http://people.inf.elte.hu/ljjsaai/home.html

(Iо) Tóbiás, R. (2010). Az érzékszervek szerepe a marketingben, avagy ha az íze, hangja, illata olyan mint egy kacsáé, akkor az minden bizonnyal egy... [szakdolgozat] Budapest: Budapesti Gazdasági Főiskola. 